\title{
The Radical New Perspective on Paul, Messianic Judaism and their connection to Christian Zionism
}

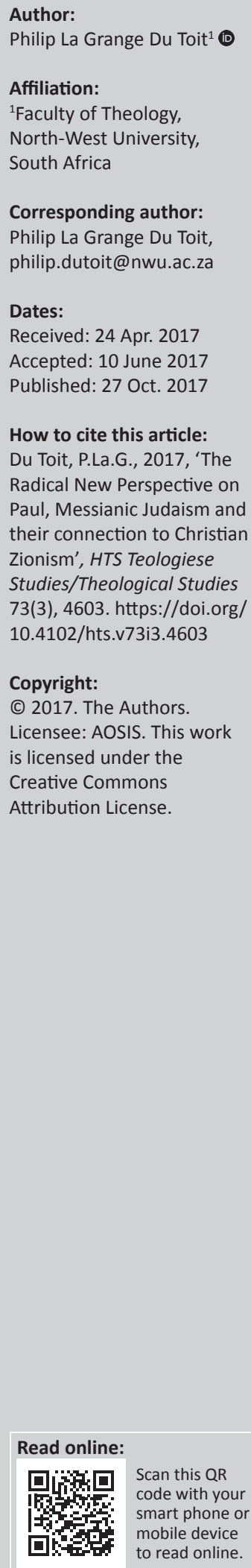

The Radical New Perspective on Paul distinguishes between two subgroups of believers in Christ in Paul's time: gentile believers and Jewish or Judaean believers. The same distinction is utilised in supporting contemporary Messianic Judaism, which presupposes an ongoing covenantal relationship between God and contemporary Jews that exists over and above Christianity. Many proponents of Christian Zionism, a Christian movement that envisions the Jews' return to the land of Israel, utilise aspects of both the Radical New Perspective on Paul and Messianic Judaism in support of their beliefs. Ironically, while the Radical New Perspective on Paul is a certain product of post-holocaust theology, Christian Zionism can be perceived as a perpetuation of a kind of imperial theology that brings injustice to Palestinian people, especially in view of a post-imperial South African context. While none of these connections are inevitable, to point out the relationship between these approaches to identity serves to rethink some of the preconceived notions behind them, as well as some of the (unintended) consequences that arise from them.

\section{Introduction}

The so-called New Perspective on Paul (NPP; Dunn 1983) and its variants certainly had a profound impact on Pauline scholarship. While these new perspectives on Paul brought new impetus to Pauline studies, studies in 1st-century Judaism and studies in identity formation, this article aims to take a step back and ask certain questions on a meta-level. The presupposition behind such an approach is that Pauline studies cannot exist in a vacuum, but are inevitably interwoven within the worldview, presuppositions, interests and even the religious and/or political agenda(s) of the researcher. To a certain extent, this is also true in respect of historical enquiry. ${ }^{1}$ Pauline studies generally influence New Testament theology and the ecclesiastical expression of the church. In fact, a certain circularity has to be acknowledged. On the one hand, Pauline scholarship has a direct or indirect influence on preachers and the religious expression of congregations that base their identity and beliefs on their interpretation of the Pauline corpus. On the other hand, the interests and focus areas of Pauline researchers are influenced by the religious expression (e.g. how the Pauline material is interpreted in the church) or political climate of the day (e.g. how Jews or Christians are perceived in the world that we live in).

In this regard, the NPP and its variants, including the so-called Radical New Perspective on Paul $(\mathrm{RNPP}),{ }^{2}$ can be considered as reactions against a negative sentiment against Jews or Judaism that is often associated with the traditional, Lutheran reading of Paul. In this sense, these perspectives on Paul are the direct results of post-Holocaust theology (cf. Heen 2010:267-268; Zetterholm 2009:127, see below). As will become clearer later on in this article, the RNPP can be seen as a certain variation on the NPP that is influenced by the political and religious climate of the day. Building on the NPP, the RNPP has gone further than the NPP in arguing for retaining a distinct Jewish identity within the Christ-believing community in the New Testament.

Two specific strands of religious expression that are interrelated with these new perspectives on Paul, especially the RNPP, are Messianic Judaism and Christian Zionism. The focus of this article is (1) to point out the relationship between the RNPP, Messianic Judaism and Christian Zionism, (2) to point out some of the main hermeneutical problems underlying the three movements and (3) to evaluate some of the preconceived notions behind the RNPP in light of these religious expressions and their effect on how the conflict in the Middle East is perceived.

1.At worst all history writing is biased (Ankersmit 1994:107, 117), and at best, cultural bias is not easy to correct or detect in historiography (McCullagh 2000:39).

2.This term was coined by Zetterholm (2009:161) 


\section{Defining the Radical New Perspective on Paul, Messianic Judaism and Christian Zionism The Radical New Perspective on Paul}

The way in which the Holocaust became a leading factor in the development of the RNPP can clearly be identified in the works of writers who moved beyond the NPP. For example, Lloyd Gaston (1987), who can be considered as one of the pioneers who moved beyond the NPP, is motivated by 'the insight that the Holocaust must result in a complete reversal of Christian theology' (Zetterholm 2009:127). John Gager (2000:150-151), who shares much common ground with both Gaston and the RNPP (see below), writes that 'the Nazi Holocaust, together with the founding of the state of Israel, ${ }^{3}$ account for the possibility of reading Paul in a new way'. Mark Nanos (2002:4), one of the prominent proponents of the RNPP, admits that he is 'a product of many factors, not least the long shadow of the Holocaust'.

The RNPP constitutes a pertinent reaction against antiJudaism and even anti-Semitism that many of its proponents perceive to be inherent to traditional Christianity (e.g. Eisenbaum 2009; Gager 2000:15; cf. Ruether 1974). ${ }^{4}$ Underlying to such a proposed corrective to Pauline theology lies the sentiment that the Holocaust was at least partly the result of a kind of Christianity that sees itself as superior to Judaism, and as superseding Judaism. In terms of the way in which the RNPP reacts against traditional Christianity, it can be understood as reacting against a kind of traditional Christianity that is perceived to be a universal (cf. Buell 2005; Hodge 2007:3), exclusive and arguably an imperialistic religion that negatively stereotypes Jews. The sentiments behind the RNPP are thus related to the same kind of reactive ethos that underlies womanist, feminist, queer and postcolonial criticism.

In reaction to Christian universalism, the RNPP approaches identity in the Pauline corpus in such a way that an ongoing distinction between believers (or followers) of Jesus ${ }^{5}$ from the Ioudaioi ('Judaeans', see below) and gentile believers in Christ is claimed. According to an RNPP reading, gentile Christ believers were subjected to a limited set of requirements, whereas all believers from the Ioudaioi would maintain full obedience to the Mosaic Law, including circumcision and dietary restrictions. This limited set of requirements for gentile believers is primarily based on a specific understanding of the Apostolic Decree in Acts 15:19-32, 16:1-5 and 21:25, which is normally argued to represent an accommodation of gentiles on the basis of Jewish halakha. This aspect of halakha, in turn, is often claimed to correspond to the so-called 'Noahide Laws' or 'Noahic Covenant' (e.g. Bockmuehl 1995,

3.Zetterholm (2009:127) also points to the formation of the State of Israel in 1948 as an important determining factor behind Gaston's work.

4.As writing before the designations NPP or RNPP came into existence, Ruether (1974) already contended that anti-Judaism is engrained within the heart of Christology and the Christian message.

5.There exists a tendency under RNPP proponents not to refer to 'Christ believers', but rather to 'Christ followers' (or similar). In this article, however, the designation rather to 'Christ followers' (or similar). In this article, however, the designation
'Christ believers' will be utilised in referring to members of the early believing community.
2000; Campbell 2008:89-93; Eisenbaum 2009:252; Gager 2000; Gaston 1987; Nanos 1996:50-56, 2012:123-124; Rudolph 2010, 2011; Tomson 1990:259-281, [1996] 2001:251-270; Tucker 2011:62-114). In Rabbinic Judaism there are seven of these Noahide Laws ${ }^{6}$ that are only applicable to gentiles. A gentile who adheres to these seven laws is accepted as a righteous gentile and could earn a place in the age to come (Blickenstaff 2009:280; Tomson 1990:50).

In association with the above notion of an intra-ecclesial distinction, the view among RNPP proponents exists that the promises to ancient Israel are considered by Paul as eternal. Although preceding the RNPP, the dual covenant view is closely related to the RNPP in this regard. In the dual covenant view, contemporary Jews, who are identified with ancient Israel, are believed to remain God's eternal people in parallel to faith in Christ. Proponents of this view believe that faith in Christ is designed for gentiles only (e.g. Gager 2000; Gaston 1987; Stendahl 1976). In both of the latter variants of Pauline theology, Paul is perceived to be thoroughly Jewish and thus to remain fully Torah-observant, including circumcision, dietary restrictions and Sabbath observance, while his letters are perceived to be directed towards gentiles or gentile Christ believers only.

\section{Messianic Judaism}

Messianic Judaism is a relatively recent phenomenon that received impetus from the Jesus movement in the 1960s and became known as Messianic Judaism in the 1970s (Ariel 2006:191, 194-195; Kinzer 2000:3, 6; UMJC 2013:16). The flourishing of this movement is also related to living in a post-Holocaust world and the subsequent new way of relating to Jews (Glaser 2013:119; Kinzer 2000:26, 42; Rosner 2013:145). Messianic Jews see themselves as essentially Jewish rather than being (Hebrew) Christians (Ariel 2006:195; Kinzer 2000:4; 2013:131-132). In Messianic Judaism, 'Judaism' is considered to be the genus, whereas 'Messianic' is considered the species, which signifies the priority of their connection and identification with the Jewish people and their religious tradition. In terms of being messianic, they recognise Jesus Christ as Messiah, while considering the New Testament as apostolic and authoritative, but not necessarily at the cost of disregarding the Talmud or other Jewish writings (Kinzer 2000:4-8). Being essentially Jewish, Messianic Jews adhere to the Mosaic Law as well as Jewish culture and tradition (e.g. Jewish feasts and Sabbaths, dietary laws, circumcision and gathering in synagogues). In trusting in Jesus as Messiah for salvation (UMJC 2004; 2013:2), they do not consider adherence to the Law as a prerequisite for salvation (Ariel 2006:209,213).

Messianic Jews see themselves as a link or bridge between gentile people of God (Christians) ${ }^{7}$ and the Jews, whom they

6.The Noahide Laws is contained in the Mishneh Torah (Hilkhot Melakhim 8:14, 12 th century CE), and includes prohibitions on (1) idolatry, (2) blasphemy, (3) murder, (4) theft, (5) sexual immorality, (6) eating living flesh and (7) exhortations for the establishment of courts of justice.

7.Because in Judaism the designation 'Christians' is normally identified with the gentiles (goyim), Messianic Jews differentiate being messianic from being Christian (Kinzer 2000:4). 
see as God's eternal people (cf. Kinzer 2000; Woods 2014b:129). In general Messianic Jews base their unique identity on the same perceived ongoing distinction in the New Testament between gentile and Judaean Christ believers as is advanced by the RNPP, including references to the Noahide Laws (Juster 1995:68-87; Kinzer 2000:32-39; Lancaster 2011; UMJC 2013:22-24; Woods 2012; 2014a; 2014b; 2015). Proponents of the RNPP are thus often cited in support of the Messianic Jewish identity (e.g. Kinzer 2000:37; Lancaster 2011; Rosner 2013:153; Woods 2012; 2014b).

\section{Christian Zionism}

Zionism is a Jewish nationalist movement that aspires for the establishment of a homeland in Palestine. With the Balfour Declaration in 1917, Zionism developed into an international movement with support from international powers such as the United Kingdom (UK) and the United States (US). Christian Zionism, in turn, supports Zionism on Christian, theological grounds. This includes seeing the establishment of the State of Israel in 1948 as a fulfilment of biblical prophecy. Christian Zionists also envision permanent validity in the promises to ancient Israel, especially about the promised land, which involves Jerusalem and the temple. They apply the promises to Abraham about the promised land (e.g. Gn 12:1-3, 13:15, 17:8, 28:13) in a literal way to the modern state of Israel, whose citizens they consider to be descendants of Abraham. In addition, most Christian Zionists hold premillennialist dispensationalist views, which include beliefs about a future mass conversion of Jews, a literal future millennial reign of peace from the current Jerusalem, the rebuilding of the temple and the reinstatement of the Old Testament sacrificial system. The formation of the modern State of Israel in 1948 is normally considered as a signal of the last days having arrived (e.g. Baker 1971; Pawson 2008; Ryrie 1995; cf. Abraham \& Boer 2009:90-91; Church 2009:376-378; Paas 2012:13-14; Wagner 1992:4).

Although Christian Zionism has never enjoyed much support in New Testament scholarship as such, it is regarded as a 'standard position among the evangelical Protestant religious right, especially in the United States of America' (Abraham \& Boer 2009:91) and arguably in much of Western Christianity, including South Africa. Although controversial, much of the US's contemporary war on terror, its support for the State of Israel and its antagonism towards Israel's enemies can be connected to a strong pro-Israeli lobby within the US, which in turn derives much support from Christian Zionists (Sizer 2004:213-215; Wagner 1992:4-5). Vocal or popular supporters of the Christian Zionist cause include figures such as $\mathrm{Hal}$ Lindsey, Jerry Falwell, Pat Robertson, Oral Roberts, John Hagee (see Sizer 2004:22-24), David Pawson (2008) and the prominent Calvinist Baptist, John MacArthur (e.g. MacArthur 2012). In light of a postcolonial and a post-apartheid South African context, Christian Zionism can be regarded as a kind of Imperial Theology that perpetuates injustice against the Palestinians. The latter notion is embodied in the so-called Kairos Palestine, a document compiled by Palestinian Christians in 2009. This document is based on the similar plight embodied by the original South African Kairos Document of 1985 that originated in Soweto against the apartheid regime. The Kairos Palestine document constitutes the plight of Palestinian Christians and other Palestinians against Israeli occupation (see Kairos Palestine 2009). Kairos Palestine was followed by Kairos US in 2011 (see Kairos USA 2011), a response from American Christians who acknowledged and identified with the plight of the Palestinians in Israel. The influence of Christian Zionism in shaping the political world, especially in terms of the way in which the Middle East Conflict is perceived, is thus probably stronger than is usually acknowledged.

\section{Commonalities between the Radical New Perspective on Paul, Messianic Judaism and Christian Zionism}

Firstly, the RNPP, Messianic Judaism and Christian Zionism can all be considered as being influenced by the Holocaust. Although Zionism was underway before the Holocaust, the formation of the State of Israel in 1948 that followed the Holocaust can be considered as a landmark in the Zionist movement. Large-scale Christian support for the Zionist movement gained momentum after the formation of the State of Israel (cf. Paas 2012:8, 90). So, for example, the state of Israel gave official encouragement to Christian Zionism by allowing the establishment of the International Christian Embassy Jerusalem in 1980. The International Christian Embassy Jerusalem is in itself a Christian Zionist organisation.

Secondly, in accordance with new perspective readings of Paul, all three movements portray Judaism and Jews in a positive light and accentuate Judaism's continuity with biblical Israel. All of them thus confirm the identity and the religious rights of the Jewish people in modern times. At the same time they repudiate anti-Semitism or negative prejudice against Jews.

Thirdly, all three movements confirm some form of eternal covenant of God with the Jewish people. While Christian Zionists do not necessarily affirm Jews' salvation apart from Christ, they perceive God's promises to biblical Israel as eternal, especially about the promised land. Proponents of the RNPP and Messianic Jews also confirm God's eternal covenant with Israel and especially their relation to the Law, but not necessarily to the exclusion of the establishment of the Jewish people in the land of Israel (see below). In other words, the latter two movements confirm the ongoing identity of the Jews as God's people, and not only the permanence of God's promises to them.

Fourthly, all three movements take a stance against some form of traditional Christianity. Both the RNPP and Messianic Judaism react against claims of universality in Christianity and especially against the idea that Christianity has replaced biblical Israel. In perceiving Paul as fully within Judaism, the RNPP in particular problematises traditional Christianity's claim on Paul, although the latter notion is not necessarily 
expressed. While many Christian Zionists also react against replacement theology, they generally hold dispensationalist views (see above), implying that God's dealings with Israel are temporarily set aside until the end time when God would revert back to Israel.

Fifthly, all of these movements in some way accentuate the Jewish roots or Hebraic roots of belief in Christ. In situating Paul within Judaism, it follows naturally that the RNPP accentuates the Jewish roots of faith in Christ (e.g. Campbell 2008:17, 31; Nanos 1996:32, 293). Nanos even contends that Paul in his letter to the Romans addressed gentile Christians 'without a proper understanding of their roots in Jewish faith' (Nanos 1996:100; cf. Wright 1991:251). The same is true in respect of Messianic Judaism. A prominent Messianic Jew, Daniel Juster (1995), titled his book: Jewish roots: A foundation of Biblical theology. Rudolph and Klayman (2013:49) see the Messianic Jewish synagogue as facilitating in teaching gentile Christians the 'Jewish roots of their New Covenant faith' (cf. Glaser 2013:123). Needless to point out, the notion that Christians should be taught their Jewish roots has been part and parcel of many Christian Zionist organisations such as The London Society for Promoting Christianity Amongst the Jews that was founded in 1809 (Crombie 1991:3), until they later developed into The Church's Ministry Among Jewish People in 1995 (Church's Ministry Among Jewish People 1995). To instruct Christian believers in the 'Hebraic roots of their faith' formed part of the beliefs of the third Christian Zionist Congress held in Jerusalem in February 1996 (Sizer 2007). The same applies for the Christian Zionist organisation Bridges for Peace (Merkley 2001:169).

Sixthly, there seems to be a considerable amount of overlap in the writings of RNPP proponents, Messianic Jews and Christian Zionists. Apart from Messianic Jews that regularly quote RNPP proponents in support of their viewpoints (see above), a fairly recent edited work, Introduction to Messianic Judaism: Its Ecclesial Context and Biblical Foundations (Rudolph \& Willits 2013), features the contributions of RNPP proponents such as David Rudolph, William S. Campbell and Markus Bockmuehl. It is noteworthy that Rudolph is both a Messianic Jew and an RNPP proponent (see Rudolph 2010). This is evidence of the close relationship between the RNPP and Messianic Judaism. In respect of the relationship between the RNPP and Messianic Judaism, Jennifer Rosner (2013), a contributor to the same volume (Rudolph \& Willits 2013), writes the following about a leading RNPP proponent, Mark Nanos:

\footnotetext{
Nanos's contention that Paul upheld the covenantal requirement of circumcision and Torah observance for Jewish Christ-followers makes his interpretation a natural ally for Messianic Jewish theology. Nanos's work lends support to Messianic Judaism by revealing that Paul himself envisioned and embodied a similar religious identity. (p. 153)
}

In respect of Zionism, the progressive settlement of Messianic Jews in Israel since the mid-1950s to the early 1970s exemplifies their commitment to the Zionist cause. They aimed to 'present a Messianic Jewish alternative to the dominant prototype of secular Zionism' (Nerel 1997:19). One of the statements of the Messianic Jewish Alliance of America, one of the largest associations of Messianic Jews, includes that they 'support the Jewish people and the State of Israel' (Sizer 2004:97). Although many Messianic Jews distance themselves from the ways in which secular Zionism is practised and propagated, they stay committed to the establishment of Jewish people in the land of Israel. It has to be noted that, although many American Messianic Jews share dispensationalist views with Christian Zionists (see above), there are some that dislike dispensationalism, because 'its view on the fulfillment of the Law leads to the conclusion that Messianic Jews no longer have a covenantal responsibility to observe distinctively Jewish commandments in the Torah' (Glaser 2013:122).

In conclusion, although not all RNPP proponents are necessarily Messianic Jews, the theological views of both movements are mutually inclusive in respect of (1) their perceived ongoing intra-ecclesial distinction between Judaean and gentile believers in the New Testament and (2) their belief that Judaean believers stay in an ongoing relation to the Law in terms of their identity. While Messianic Jews, who do not generally refer to themselves as 'Christians', cannot be 'Christian' Zionists in the strict sense, they are generally Zionist in that they normally support the national state of Israel and in that many subscribe to premillennial dispensationalist views, especially in the US.

\section{Hermeneutical problems}

Before some of the preconceived notions behind the RNPP and its consequences can be evaluated, some of the hermeneutical problems behind all of the three abovementioned movements have to be identified. While it is impossible to evaluate all three movements in detail within the scope of this article, and because I have engaged in such evaluations in previous publications (see Du Toit 2015a:2830; 2016a; 2016b), the focus will be on some of the main points of contention. Yet, even these main points of contention will be presented in the form of an overview.

One of the foremost hermeneutical problems behind all three movements is the hermeneutical distance between contemporary Jews, the Ioudaioi of the 1st-century and biblical Israel. As indicated before (Du Toit 2015b:420-422; 2016d:206-210), in the 1st century CE the designations Israêl and Israelitees were mostly used to point to ancient, historical Israel as God's elect people. However, in the 1st century, the term Ioudaios was more of an ethnic designation ${ }^{8}$ for people living in that time that descended from ancient Israel, without pertinent connotations about being God's elect people. This tendency was largely influenced by the Exile and can especially be identified with Josephus (Ant. 11.169-173).

8.Although some understand the concept of ethnicity as a cultural construct and matter of self-ascription (Punt 2012:4; cf. Campbell 2008:3-5), the term 'ethnicity' matter of self-ascription (Punt 2012:4; cf. Campbell 2008:3-5), the term 'ethnicity' or 'ethnic' is noramlly used in a more restricted way to denote 'a group's shared biological origins' and in a broader sense to resemble 'the concept of nationality' (Weeks 2011), which includes things such as ancestral traditions, customs, norms, conventions, mores and laws (Mason 2007.484). In this article it is used somewhere in the middle between the latter two connotations with perhaps a slight preference towards the biological side. 
I argued at some length elsewhere that Paul also used these designations in this way, including in Romans 11:26 and Galatians 6:16 (Du Toit 2013a; 2015b; 2016d).

Another contributing factor to the hermeneutical distance between contemporary Jews and the Ioudaioi of the first century is the fact that the faith of the Ioudaioi cannot be considered as a 'religion' in the full sense of the word, even though it did contain 'religious' elements (Mason 2007). Miller (2014:255) argues that the Ioudaioi did have a concept of religion even though there was no generally accepted term for it. He points out that there was a measure of overlap between what ancient people considered as distinct about the Ioudaioi and what is conventionally regarded as religion. But even so, one has to account for the fact that formative Judaism was largely a development after 70 CE (Langer 2003:258; Mason 2007:502; Neusner 1984:1-5). In other words, although one can acknowledge elements of religion in the faith of the Ioudaioi before $70 \mathrm{CE}$, such elements have to be distinguished from the way in which Rabbinic Judaism came into being as a full-scale religious system. This is in fact the reason why many New Testament scholars refer to the Ioudaioi of the 1st century as 'Judaeans' rather than 'Jews', in order to avoid anachronism (e.g. Bauer et al. 2000; Malina \& Rohrbaugh 1992:32, sv. Ioudaios; Elliott 2007; Esler 2003; Mason 2007). The same kind of anachronism is at play in retrojecting the later Rabbinic Judaist concept of the Noahide Laws into the New Testament, a concept that can hardly be traced to pre-Rabbinic times (Du Toit 2013b).

In terms of the perceived intra-ecclesial distinction between Judaean and gentile believers in Christ (RNPP and Messianic Jews), I have argued that the Apostolic Decree (Ac 15:19-32, $16: 1-5,21: 25)$ does not necessarily entail a set of minimum requirements for gentile believers to be included as members of the Judaean believing community. The Apostolic Decree was rather a kind of compromise on the side of the gentile Christ believers that took their Judaean Christ-believing members into consideration. By adhering to certain Mosaic guidelines they would not offend their Judaean brothers and sisters and thus accommodate their 'weak' conscience. ${ }^{9}$ Such an accommodation would then correspond to a similar situation portrayed in Romans 14, where Judaean believers who still wanted to adhere to the full Torah were considered as 'weak'. In addition, we have no evidence from Acts or elsewhere that all Judaean believers in the early believing community insisted that all other Judaean believers should observe the whole Torah (including circumcision, dietary restrictions, Sabbaths, etc.) in distinction from gentile believers, even though such a group might have been great in number (Du Toit 2016e:2-4).

The belief that Paul was fully Torah observant, including adherence to ritual requirements such as circumcision and dietary laws, that normally accompany the RNPP and

g. Although the avoidance of ropvsio one of the demands la.................... 15:19), might involve a general ethical reprimand against sexual immorality, it 15:19), might involve a general ethical reprimand against sexual immorality, it probably points to the sexual immorality associated with pagan religious festivals
(cf. 1 Cor 10:7-8; Witherington 1998:466). The rest of the demands can all be (cf. 1 Cor 10:7-8; Witherington 1998:466
connected to Judaean ritual requirements.
Messianic Judaism, is highly contestable. I have argued in some length elsewhere that the picture of Paul that is painted in the Acts of the Apostles does not necessarily entail full Torah observance on Paul's part. This includes Paul's circumcision of Timothy (16:3), Paul's participation in purification rites $(18: 18,21: 17-26)$ and his reference to himself as a Judaean $(21: 39 ; 22: 3)$ or a Pharisee $(23: 6 ; 26: 5)$. All of the latter events can be accounted for by the principle Paul laid out in 1 Corinthians 9:19-23 to be everything to everyone in order to 'win' them for the gospel, especially if the polemical context in which these events in Acts took place is taken into account (Du Toit 2016e). ${ }^{10}$ The contention that Paul would be fully Torah observant, based on his reference to his Pharisaic life (Phil 3:3-6) or being a Hebraios and an Israelitēs (2 Cor 11:22; Nanos 2009:4), can be understood as denoting his ethnic and cultural heritage rather than denoting his current identity in Christ (Du Toit 2013a:60-64, 187-191). Even Paul's reference to being a Judaean fusei (Gl 2:15), can merely denote his birth status (Du Toit 2013a:185) rather than pointing at a full, Law-observant, Judaean identity.

The often-referenced 1 Corinthians 7:17-24 by RNPP proponents to legitimise an intra-ecclesial distinction or Paul's full adherence to the Torah is contestable too (Du Toit 2015a). Paul's reference to the 'keeping of the commandments of God' (v. 19), which he contrasts to the irrelevance of physical circumcision, could in fact be a shorthand reference to the obligation to adhere to the whole Torah if one reverts to an 'old-age' attitude that prevailed before the 'coming' of faith (Gl 2:23, 25). The latter notion would be similar to (1) Paul's reference in Romans 2:12-29 to such an obligation under the Law (Du Toit 2016c) and (2) his reference in Galatians 5:1-6 to the obligation to do the whole Law if one let oneself be circumcised (Du Toit 2015a:35-40).

Further, the notion that the letter to the Galatians would solely be directed to gentile believers, a notion that is often present with RNPP proponents (e.g. Nanos 2002) and Messianic Jews (e.g. Lancaster 2011), is problematic to maintain against the first-person singular and plural in the context of the freedom of the Law or the new position in Christ in the letter. When Paul writes in the first-person singular (2:19-21) he includes himself as having died to the Law. Similarly, when he utilises the first-person plural in the letter $(1: 4,2: 4,5,15,16,17 ; 3: 13,14,23-25 ; 4: 3,5,6,26,28,31$; $5: 1,5,25)$, Paul includes and implicates himself in respect of believers' position in relation to the Law. Alternatively, the referents of the 'we' language have to be changed arbitrarily in order to uphold the view that Paul is applying his exposition(s) about the new position in which believers stand

10.In 1 Corinthians $9: 20$ Paul specifically states that he is not himself under the Law

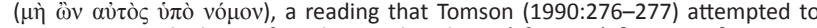
argue away on the basis of weak textual evidence (cf. Juster's [1995:107] omission of this phrase from his quotation of 1 Cor 9:20). In respect of 1 Corinthians $9 \cdot 19$ of this phrase from his quotation of 1 Cor 9:20). In respect of 1 Corinthians 9:1923, Thave argued with Wright (2013:1437-1439) against the almost 'postmodern' notion of Nanos (2012:129-130,139) that Paul would want to communicate in 'cross-culturally intelligible terms' and merely wanted to meet people rhetorically, or Tucker's (2011:102-107) contention that Paul would have made a halakhi ifferenciation between two types of Judaeans in verse 20, where one Judaean group would adhere to a stricter interpretation of the Torah than another Judaean group. The main problem is that in the halakhic interpretation, Paul would not have given up anything (Du Toit 2015a:32-35). 
in respect of the Law to gentile believers only. ${ }^{11}$ Regarding Galatians 3:28, while RNPP proponents (e.g. Nanos 2009:4-5) and Messianic Jews (e.g. Juster 1995:111; Woods 2014b:120) are right that the distinctions between Judaean, Greek, slave, free, male and female are not eradicated in Christ, in Pauline terms, none of these identities are constitutive of one's identity as Abraham's child (3:7) or God's child (3:26) either. In Christ, one's core identity is defined by Christ (cf. 2:20). Being male, female, slave or free does not contribute to one's status in Christ. The same is true for being a Judaean who came to belief in Christ. In Messianic Judaism, however, being a Jew (the genus) is very much constitutive of one's status before God. Circumcision was not merely a cultural symbol but a sign of the covenant (Gn 17:11-14). Similarly, the Law marked Israel as God's people and ensured their life and multiplication in the land (Lv 18:5; Dt 4:1, 8:1). Mixing (contemporary) Judaism with faith in Christ thus cannot be on the same level as being male, female, slave or free. Paul rather uses Ioudaios in a mere ethnical sense without connotations about being God's people (see above; see also Du Toit 2016b:106-108).

The idea that Romans 11:25-27 points to a future promise to current Jews is questionable on several counts. Apart from the distinctions between the designations Israèl or Israelitēs and Ioudaios and the hermeneutical distance between current Jews and the Judaeans in the 1st century (see above), as argued elsewhere (Du Toit 2015b), this passage does not have to indicate a promise in Paul's future either. It can in fact be interpreted as a logical future pertaining to ancient, historical Israel, that is future of the promise ( $\mathrm{Rm} \mathrm{11:26b-27)} \mathrm{but}$ already fulfilled in Christ. Such a conclusion would be conceivable in light of the question about the destiny of ancient Israel that underlies Paul's exposition of the culmination of salvation history in Romans 1-11. This reading would also fit Romans 11:28-32, especially in light of the prevalence of the term nun in vv. 30-31, indicating the realised significance of the Christ event.

A hermeneutical problem that specifically applies to Christian Zionism is the way in which the concept of the promised land, which involves Jerusalem and the temple, is interpreted in the New Testament. As argued elsewhere (Du Toit 2016a), in the New Testament God's kingdom is portrayed in such a way that the inheritance of the land is incorporated, fulfilled but transferred to believers in Christ, not as an earthly territory, but as an inheritance of eternal rest in Christ (Jn $3: 3-5,4: 20-24 ; 15: 1-6 ;^{12}$ Heb 4:8-9; 11:8-10; 12:22-23, 28), as inheriting the whole cosmos under Christ's lordship (Mt 5:5 ${ }^{13}$;

\footnotetext{
11.Within an RNPP reading, it is quite strenuous for example to apply the "we' language in 3:23-25 either to gentile believers only, or to Judaean believers only. It is quite natural to envision ancient Israel as being under the Law, implying that in Christ, Judaean believers are not 'under the Law' any longer. To envision that only gentiles were under the Law in the old age before faith 'came' salvation historically would not make sense. In the light of everything being included under $\sin (3.22)$ and other utterances of Paul where he seemed to have included gentiles under the or a Law in some way ( $\mathrm{Rm} 2 \cdot 14$ ) it makes more sense that Paul saw both Israel and gentiles as being 'under the Law' in the old era (cf. De Boer 2011:238; Moo 2013:241).

12.The vine metaphor recalls Isaiah 5:1-8, which portrays Israel's rootedness in the land (see Du Toit 2016a:2).

13.Matthew uses ge, the same word that is used in the NT and the Septuagint for both the 'earth' and the (promised) 'land'.
}

Rm 4:13-14; Gl 3:29), ${ }^{14}$ and as inheriting the new heaven and 'earth' or 'land' $(g \bar{e})$ in the consummation ( $R v$ 21:1-3). The promise about the new $g \bar{e}$ is set in Revelation 21:1-3 within the same promise of Leviticus 26:11-12 and Ezekiel 37:27. In both the latter passages this promise is given within the context of the restoration of God's people in the promised land (Lv 26:1-10, 14-20; Ezk 37:12, 14, 21, 22, 25). Further, according to Paul the 'Jerusalem above', not an earthly Jerusalem, is a present reality in which believers already share (Gl 4:25-26). ${ }^{15}$ According to Paul, even the temple has been fulfilled in believers; they themselves are God's temple and partake in the actual promise of Leviticus 26:11-12 and Ezekiel 37:27, which originally included land (2 Cor 6:16; see Du Toit 2016a:5).

\section{Evaluating some of the unintended consequences of the Radical New Perspective on Paul, Messianic Judaism and Christian Zionism}

In view of the above discussion it follows that the RNPP, Messianic Judaism and Christian Zionism share many preconceived notions and beliefs. The notion that an ongoing intra-ecclesial distinction would be upheld in Paul's mind and the notion that Paul's writings are solely directed to gentile believers (RNPP and Messianic Judaism) imply that nothing in terms of the core identity of Judaeans has changed in Christ. It further implies that Judaean believers stand in the exact same covenant with God as ancient Israel, including the same eternal promises and requirements for covenantal membership, which, in turn, threatens to render the role of Christ as the Saviour of Israel (Ac 5:31) redundant. As indicated above, the intra-ecclesial position is hermeneutically problematic on several grounds and can in fact be considered a post-biblical Rabbinic Jewish notion (cf. the Noahide Laws) that is anachronistically retrojected into the New Testament.

In certain respects it can be argued that Christian Zionism finds legitimisation in the RNPP and Messianic Judaism. Christian Zionism finds support in the notion behind both the RNPP and Messianic Judaism that the promises to ancient Israel would be eternally (and literally?) valid. Although not all Christian Zionists necessarily see contemporary Jews as being God's saved people or God's second people, a kind of eternal covenant relationship between God and contemporary Jews has to be presupposed in order for God's promises to have eternal application to them. As proposed above (and argued in more length elsewhere, Du Toit 2016a), however, if such a notion is highly contestable in light of the way that the New Testament interprets the original promises to Israel, one has to ask what lies behind the upholding of such beliefs. 14. Believers partake in the (whole) promise to Abraham through faith in Christ, who
is Abraham's single seed (GI 3:16). Yet the promise to Abraham originally involved
land. Galatians $3: 29$ thus implies that even the promise to the land is fulfilled in Christ in some way (see Du Toit 2016a:3).

15.Cf. Hebrews 12:22-23 that reports of 'Mount Zion', 'the city of the living God, the heavenly Jerusalem', and of 'the assembly of the firstborn who are enrolled in heaven' (English Standard Version) to which believers have come already. 
In terms of the shared relationship of all three movements with post-Holocaust theology, a deep-seated irony seems to be lurking beneath the surface. If Christian Zionism, which is influenced by injustice against Jews (the Holocaust), can be understood as a kind of Imperial Theology that perpetuates injustice against Palestinians and Palestinian Christians, with much support from global players such as the US and the UK, is one injustice (the Holocaust) not exchanged for another form of injustice? If Christians are partly the victims of Christian Zionism (Palestinian Christians), does the idea of 'Christian Zionism' not deconstruct itself? Further, if the RNPP and Messianic Judaism cannot be completely separated from (Christian) Zionism, can one not question their emphasis on upholding an eternal covenant relationship with Jewish believers within the Christ-believing community? Or, if the RNPP would distance itself from Christian Zionism, why would it be necessary to infuse the ekklesia with the sustaining of a subgroup within them that enjoys (literal) fulfilment of the promises to ancient Israel over against gentile believers who do not share in (all of) these promises? Is the latter not a form of imbalance and even injustice in itself?

All three movements in some way react against the universalistic notion of eradicating internal status distinctions or at least distinctions in terms of core identity within the ecclesia, which is often perceived as the socalled 'replacement theology'. Although Christian Zionism does not necessarily draw such a distinction explicitly, a distinction in respect of the covenant status between Christians and Jews is implied in sustaining the idea of eternal promises to the Jews apart from the ecclesia. It is in fact a question whether the reaction from all three movements against the so-called 'replacement theology' does not lead to another form of 'replacement theology'. Is the way in which the culmination of the history of ancient Israel in Christ is interpreted in the New Testament (although such interpretations are not necessarily uniform) not replaced by ideas stemming from contemporary Judaism? Put in another way, are the reaction(s) against what is often perceived as replacement theology not against Christians holding such viewpoints and thus anti-Christian in this regard? If so, such a stance can lead to another form of antagonism, and that is namely antagonism against Christianity itself, or at least against prominent traditional expressions thereof.

Lastly, it has to be asked to which extent the theological or ideological programme of these movements are circular in nature, even though such an ideology might be subtle or even function on a subconscious level. Is an intra-ecclesial distinction or the eternal continuation of all the covenants and promises to ancient Israel really inherent to the Pauline corpus, or is it anachronistically retrojected into the New Testament text? Although a measure of circularity is inevitable in all hermeneutics, the identification and critiquing of underlying preconceived notions of interpreters should remain part and parcel of the New Testament scholarly enterprise.

\section{Conclusion}

In conclusion, the RNPP, Messianic Judaism and Christian Zionism can all be understood as preserving the particularism of the Jewish identity in the midst of or arguably against Christianity. It has been argued that all three movements share beliefs about an ongoing covenantal relationship between God and contemporary Jews that result in some form of distinction between God's people. It is presupposed that all three approaches are connected to a certain worldview or interests on the part of the researcher or adherent of any of these views. In other words, preconceived notions also underlie historical enquiry, even though such notions might be subtle or hard to identify. In considering the postcolonial and post-imperial context of today's theological enterprise, it is indeed ironic that Christian Zionism, which in itself involves a certain reaction to injustice against Jews, perpetuates a kind of Imperial Theology that brings injustice to Palestinians, including Palestinian Christians. The irony is heightened when it is considered that the possibility of such a self-destructing hermeneutic is arguably already locked up in the RNPP and Messianic Judaism. Finally, does the notion of universalism in traditional Christianity inevitably have to lead to injustice against Jews? In Pauline terms, the latter attitude is rather a result of the inherent corruptness of all people (Rm 3:9-19). It seems that the perpetuation of inherent distinctions within the Christ-believing community is more in danger of leading to forms of injustice and intolerance than the notion that all people are equal in all respects, especially in respect of covenant status.

\section{Acknowledgements Competing interests}

The author declares that he has no financial or personal relationships which may have inappropriately influenced him in writing this article.

\section{References}

Abraham, I. \& Boer, R., 2009, “'God Doesn't Care": The contradictions of Christian Zionism', Religion \& Theology 16, 90-110. https://doi.org/10.1163/156973109X450037

Ankersmit, F.R., 1994, 'The origins of postmodernist historiography', in J. Topolski (ed.), Historiography between modernism and postmodernism: Contributions to the methodology of historical research, pp. 87-118, Rodopi, Amsterdam.

Ariel, Y., 2006, 'Judaism and Christianity Unite!: The unique culture of Messianic Judaism', in E.V. Gallagher \& W.M. Ashcraft (eds.), Introduction to new and alternative religions in America: Jewish and Christian traditions, vol. 2, pp. 191-221, Greenwood, Westport.

Baker, C.F., 1971, A dispensational theology, Grace Publications, Grand Rapids, MI.

Bauer, W., Danker, F.W., Arndt, W.F. \& Gingrich, F.W. (eds.), 2000, A Greek-English lexicon of the New Testament and other early Christian literature (BDAG), University of Chicago Press, Chicago, IL.

Blickenstaff, M., 2009, 'Noahide Laws', in K.D. Sakenfeld (ed.), The new interpreter's dictionary of the Bible, vol. 4, p. 280, Abingron, Nashville, TN.

Bockmuehl, M.N.A., 1995, 'The Noachide Commandments and New Testament ethics: With special reference to Acts 15 and Pauline Halakhah', Revue Biblique 102, 72-101.

Bockmuehl, M.N.A., 2000, Jewish law in gentile churches, T\&T Clark, Edinburgh.

Buell, D.K., 2005, Why this new race: Ethnic reasoning in early Christianity, Columbia University Press, New York, NY.

Campbell, W.S., 2008, Paul and the creation of Christian identity, T\&T Clark, London.

Church, P.A.F., 2009, 'Dispensational Christian Zionism: A strange but acceptable Aberration or a Deviant Heresy?', Westminster Theological Journal 71, 375-398.

Church's Ministry among Jewish People, 1995, About CMJ, viewed 21 February 2017, from http://www.cmj-israel.org 
Crombie, K., 1991, For the Love of Zion: Christian witness and the restoration of Israel, Hodder \& Stoughton, London.

De Boer, M.C., 2011, Galatians: A commentary, Westminster John Knox Press, Louisville, KY. (The New Testament Library).

Dunn, J.D.G., 1983, 'The New Perspective on Paul', Bulletin of the John Rylands Library 65, 95-122.

Du Toit, P.La G., 2013a, 'Paul and Israel: Flesh, spirit and identity', PhD dissertation, Stellenbosch University, Stellenbosch.

Du Toit, P.La G., 2013b, 'Perspektiewe op die Noagitiese Wette by Paulus, en die Belang Daarvan vir Joods-Christelike Dialoog', Litnet Akademies 10(1), 631-656.

Du Toit, P.La G., 2015a, 'Paul's reference to the "Keeping of the Commandments of God" in 1 Corinthians 7:19', Neotestamentica 49(1), 21-45.

Du Toit, P.La G., 2015b, 'The salvation of "All Israel" in Romans 11:25-27 as the salvation of inner-elect, historical Israel in Christ', Neotestamentica 49(2), 417-452.

Du Toit, P.La G., 2016a, 'Does the New Testament support Christian Zionism?', In Luce Verbi 50(1), 1-9.

Du Toit, P.La G., 2016b, 'Does the New Testament support Messianic Judaism?', Conspectus 22, 81-123.

Du Toit, P.La G., 2016c, 'Paul's radicalisation of law-obedience in Romans 2: The Plight of someone under the law', In Luce Verbi 50(1), 1-8.

Du Toit, P.La G., 2016d, 'Reading Galatians 6:16 in line with Paul's contrast between the new aeon in Christ and the old aeon before the Christ event', Stellenbosch Theological Journal 2(2), 203-225.

Du Toit, P.La G., 2016e, 'Was Paul fully Torah observant according to acts?', HTS Theological Studies 72(3), 1-9. https://doi.org/10.4102/hts.v72i3.3396

Eisenbaum, P., 2009, Paul was not a Christian: The original message of a misunderstood apostle, HarperCollins, New York.

Elliott, J.H., 2007, 'Jesus the Israelite was neither a "Jew" nor a "Christian": On correcting misleading nomenclature', Journal for the Study of the Historical Jesus correcting misleading nomenclature', Journal for the Study of th
5(2), 119-154. https://doi.org/10.1177/1476869007079741

Esler, P.F., 2003, Conflict and identity in Romans: The social reading of Paul's letter, Fortress Press, Minneapolis, MN.

Gager, J.G., 2000, Reinventing Paul, Oxford University Press, New York.

Gaston, L., 1987, Paul and the Torah, University of British Columbia Press, Vancouver.

Glaser, M., 2013, 'Messianic Jewish National Organizations', in D. Rudolph \& J. Willitts (eds.), Introduction to Messianic Judaism: Its ecclesial context and biblical foundations, pp. 116-125, Zondervan, Grand Rapids, MI.

Heen, E.M., 2010, 'A Lutheran response to the new perspective on Paul', Lutheran Quarterly 24(3), 263-291.

Hodge, C.E.J., 2007, If sons then heirs: A study of kinship and ethnicity in the Letters of Paul, Oxford University Press, New York.

Juster, D., 1995, Jewish roots: A foundation of Biblical theology, Destiny Image Publishers, Shippensburg.

Kairos Palestine, 2009, Kairos document, viewed 19 February 2017, from http://www. kairospalestine.ps/index.php/about-us/kairos-palestine-document

Kairos USA, 2011, Call to action: U.S. Response to the Kairos Palestine document viewed 19 February 2017, from http://kairosusa.org/wp-content/uploads/2013/ viewed 19 February 2017, from hairos-USA-Call-to-Action.pdf

Kinzer, M., 2000, The nature of Messianic Judaism: Judaism as genus, Messianic as species, Hashivenu Archives, West Hartford.

Kinzer, M., 2013, 'Messianic Jews and the Jewish world', in D. Rudolph \& J. Willitts (eds.), Introduction to Messianic Judaism: Its ecclesial context and Biblical foundations, pp. 126-135, Zondervan, Grand Rapids, MI.

Lancaster, D.T., 2011, The holy epistle to the Galatians: Sermons on a Messianic Jewish approach, First Fruits of Zion, Marshfield, MO.

Langer, R., 2003, 'Jewish understandings of the religious other', Theological Studies 64, 255-277. https://doi.org/10.1177/004056390306400202

MacArthur, J.F., 2012, The salvation of Israel, viewed 19 February 2017, from http:// www.gty.org/resources/sermons/90-445/the-salvation-of-israel

Malina, B.J. \& Rohrbaugh, R.L., 1992, Social-science commentary on the synoptic Gospels, Fortress Press, Minneapolis, MN.

Mason, S., 2007, 'Jews, Judaeans, Judaizing, Judaism: Problems of categorization in Ancient history', Journal for the Study of Judaism 38, 457-512. https://doi.org/ $10.1163 / 156851507 X 193108$

McCullagh, C.B., 2000, 'Bias in historical description, interpretation, and explanation', History and Theory 39(1), 39-66. https://doi.org/10.1111/0018-2656.00112

Merkley, P.C., 2001, Christian attitudes towards the State of Israel, Montreal \& Kingston, London.

Miller, D.M., 2014, 'Ethnicity, religion and the meaning of loudaios in ancient "Judaism"', Currents in Biblical Research 12, 216-265. https://doi.org/10.1177/ 1476993X13507532

Moo, D.J., 2013, Galatians, Baker Academic, Grand Rapids, MI. (Baker Exegetical Commentary of the New Testament).
Nanos, M.D., 1996, The mystery of Romans: The Jewish context of Paul's letter, Fortress Press, Minneapolis, MN.

Nanos, M.D., 2002, The irony of Galatians: Paul's letter in first-century context, Fortress Press, Minneapolis, MN.

Nanos, M.D., 2009, 'The myth of the "law-free" Paul standing between Christians and Jews', Studies in Christian-Jewish Relations 4, 1-21.

Nanos, M.D., 2012, 'Paul's relationship to Torah in light of his strategy "to become everything to everyone" (1 Corinthians 9.19-23)', in R. Bieringer \& D. Pollefeyt (eds.), Paul and Judaism: Crosscurrents in Pauline exegesis and the study of Jewish-Christian relations, pp. 106-140, T\&T Clark, London.

Nerel, G., 1997, “'Messianic Jews” in Eretz-Israel (1917-1967): Trends and changes in shaping self-identity', Mishkan 27, 9-21.

Neusner, J., 1984, Messiah in context: Israel's history and destiny in formative Judaism, Fortress Press, Philadelphia, PA.

Paas, S., 2012, Christian Zionism examined: A review of ideas on Israel, the church and the kingdom, VTR Publications, Nürnberg.

Pawson, J.D., 2008, Defending Christian Zionism, Terra Nova, Bristol.

Punt, J., 2012, '1 Corinthians 7:17-24. Identity and human dignity amidst power and liminality', Verbum et Ecclesia 33(1), 1-9. https://doi.org/10.4102/ve.v33i1.683

Rosner, J.M., 2013, 'Messianic Jews and Jewish-Christian dialogue', in D. Rudolph \& J. Willitts (eds.), Introduction to Messianic Judaism: Its ecclesial context and biblical foundations, pp. 145-155, Zondervan, Grand Rapids, MI.

Rudolph, D.J., 2010, 'Conference proceeding: Paul's "Rule in all the Churches" (1 Cor 7:17-24) and Torah-Defined Ecclesiological Variegation', Studies in ChristianJewish Relations 5, 1-24.

Rudolph, D.J., 2011, A Jew to the Jews: Jewish contours of Pauline flexibility in 1 Corinthians 9:19-23, Mohr Siebeck, Tübingen.

Rudolph, D.J. \& Klayman, E., 2013, 'Messianic Jewish Synagogues', in D. Rudolph \& J. Willitts (eds.), Introduction to Messianic Judaism: Its ecclesial context and Biblical foundations, pp. 37-50, Zondervan, Grand Rapids, MI.

Rudolph, D.J. \& Willitts, J. (eds.), 2013, Introduction to Messianic Judaism: Its ecclesial context and Biblical foundations, Zondervan, Grand Rapids, MI.

Ruether, R.R., 1974, Faith and fratricide: The theological foots of anti-Semitism, Seabury Press, New York.

Ryrie, C.C., 1995, Dispensationalism, Moody Press, Chicago, IL.

Sizer, S.R., 2004, Christian Zionism: Road-map to Armageddon?, Inter-Varsity Press, Leicester.

Sizer, S.R., 2007, 'Chapter 1. Christian Zionism defined', viewed 21 February 2017 from http://www.christianzionism.org/article/sizer05.asp

Stendahl, K., 1976, Paul among Jews and gentiles and other essays, Fortress Press, Philadelphia, PA.

Tomson, P.J., 1990, Paul and the Jewish Law: Halakha in the Letters of the apostle to the gentiles, Van Gorcum, Assen.

Tomson, P.J., [1996] 2001, 'Paul's Jewish background in view of his law teaching in 1 Cor 7', in J.D.G. Dunn (ed.), Paul and the Mosaic Law, pp. 251-270, Eerdmans, Grand Rapids, ML.

Tucker, J.B., 2011, Remain in your calling: Paul and the continuation of social identities in 1 Corinthians, Pickwick, Eugene, OR.

UMJC, 2004, 'What are the standards of the UMJC?', viewed 15 February 2017, from http://www.umjc.org/what-are-the-standards-of-the-umjc

UMJC, 2013, Introducing Messianic Judaism and the UMJC, Union of Messianic Jewish Congregations, Albuquerque, NM, viewed 14 February 2017, from http://www. umjc.org/wp-content/uploads/2013/11/Introduction-to-the-UMJC.pdf

Wagner, D.E., 1992, 'Beyond Armageddon', The Link 25(4), 1-13.

Weeks, T., 2011, 'Ethnicity', in Berkshire encyclopedia of world history, 2nd edn., Great Barrington, Berkshire, viewed 14 March 2015, from http://ez.sun.ac.za/ login?url=http://search.credoreference.com.ez.sun.ac.za/content/entry/ berkwhist/ethnicity/0

Witherington, B., III. 1998. The acts of the apostles: A socio-rhetorical commentary, Eerdmans, Grand Rapids, MI.

Woods, D.B., 2012, 'Interpreting Peter's vision in Acts 10:9-16', Conspectus 13, 171213.

Woods, D.B., 2014a, 'Diakrinō and Jew-Gentile distinction in Acts 11:12', Conspectus 18, 79-94.

Woods, D.B., 2014b, 'Jew-Gentile distinction in the one new man of Ephesians 2:15', Conspectus 18, 95-135.

Woods, D.B., 2015, 'Does Acts 15:9 Refute intra-ecclesial Jew-Gentile distinction?', Conspectus 19:105-145.

Wright, N.T, 1991, The climax of the covenant: Christ and the law in Pauline theology, Fortress Press, Milleapolis, MN.

Wright, N.T, 2013, Paul and the faithfulness of God, 2 vols., SPCK, London.

Zetterholm, M., 2009, Approaches to Paul: A student's guide to recent scholarship, Fortress Press, Minneapolis, MN. 